\title{
The Implementation of Information and Communication Technology (ICT) in English Foreign Language (EFL) Teaching
}

\author{
Hani Elmahida ${ }^{1^{*}}$, Putri Elbalqis \\ Universitas Islam Negeri Profesor Kyai Haji Saifuddin Zuhri Purwokerto \\ 1917404026@mhs.iainpurwokerto.ac.id
}

\begin{abstract}
Information and Communication Technology (ICT) useful to support English Language Teaching (ELT) for foreign language. However, this world particularly needs human resources who mastering English material and modern technology. The objective of this paper was to examine the utilization of ICT while conduct autonomous learning also to ensure teachers' abilities in the implementation of social media technology to support English Foreign Language (EFL) teaching classes. The survey used with collecting data from several young teachers by descriptive-qualitative method. Data showed four from six respondents already known ICT as well, automatically those five young teachers have appropriate ELT tools by various social media. Basically, teachers understand how important student-centered to be conducted particularly in EFL classes. In contrast, it was not balanced with the idea to develop ICT while designing interactive modern learning classes. Then, one case was found in the previous survey to be precise with high school teachers. Senior teachers just utilize one or two ICT tools in the ELT classes. The limitation of tools could make the output and outcome of the learning process is not optimal. Furthermore, this paper shows the importance of ICT integration tools and ELT which should be mastered by teachers in 4.0 era.
\end{abstract}

Key words: autonomous learning; information and communication (ict); english foreign language (efl); english language teaching (elt)

\section{A. INTRODUCTION}

In this modern life, the educational system is pursued to follows the global technology development rates. The communication skill by exchange information 
is particularly important to mastering by each teacher. Bilyalova (2017) argues the implementation of ICT is a vital aspect to enhance the educational system itself. On the other hand, the teaching process of EFL in Indonesia still in the minimum range. This fact happens because the human resources of several Indonesian English teachers have no enough knowledge about ICT implementation in classes. Particularly senior teachers who have a distinct gap with 4.0 era. However, this irony should be avoiding by do an effort to ensure each teacher mastering any technology in this era namely the counseling approach. Thus, if teachers have the higher capability in the ICT application, it could allow the changes of EFL educational system from the teacher-centered to student-centered (Bubaraye \& Effiong, 2017). Therefore, the awareness about the necessity of ICT should be accepted by teachers to design modern teaching methods in EFL classes.

Communication and information in EFL teaching is the soul of the English teaching process. In the line with that statement, Azmi (2017) emphasize the survey result have appropriate data about technology could influence the participation increase of students in the class. Moreover, there is a learning platform integration while the teacher able to balance ICT during the learning process. Nguyen \& Tri (2017) revealed the majority of students utilize English Online Dictionary in the concern of language translation and the internet to find out any English material. In addition, many applications from Google Play store could be accessed by the teachers as learning tools, such as Google Classroom, Quizziz, Grammarly, YouTube and Google Podcast. Those some example of ICT media which could utilize in EFL classes. Furthermore, Ammani \& Aparanjani (2016) state ICT is officially included by the government in the Indonesian educational curriculum. Thus, several data indicate that the teachers directly pursued to cultivate technology in ELT for foreign language. ICT is the technology that provides many tools to help someone or some institution. In the 
educational institution, the existence of ICT is necessary to be developed by each teacher. Then, teachers could utilize social sites such, Facebook, Twitter, Blog, Wikipedia and any messaging application (Nguyen \& Tri, 2017). Although, teachers or perhaps educational institutions are supposed to creating their websites. If this is already conducted, it could be confirmed that the teacher capable to organize new innovations of technology. Not only create but the implementation of the website or perhaps any other social application should be appropriate in the learning process of foreign language. Based on that statement, the discussion range of this paper is about the utilization of ICT in daily teaching EFL. Moreover, the discussion is around the teachers' ability to implement social media in ICT for EFL classes and the utilization of ICT to conduct autonomous learning. The discussion is aimed to give the insight to develop teachers' creativity in any language skill through several applications with conduct studentcentered approach. Thus, teachers' awareness about 4.0 era is needed for educational incensement.

ICT and ELT are a unity, particularly in EFL. Another thing which necessary to be handled except for mastering all the related material is processing the technology which provides in the 4.0 era into a modern teaching strategy. This paper explains two different points, for instance, teachers' ability to implement ICT in EFL classes and the utilization of social media to conduct autonomous learning. Teachers' understanding and application of ICT determine the successful result in the learning process, proved by the quality of students in each class. Many educational institutions require global technologies to combine teaching strategies while follows modernization (Jayanthi \& Kumar, 2016). Then, the open-ended questionnaire used to make an analysis of how the ICT implementation particularly in 4.0 era to supports autonomous learning. Thus, 
ICT influence students' comprehension of language skill, like writing, speaking, reading and listening. Therefore, ICT and teaching skill is related each other.

This paper discusses distinct points about the implementation of ICT in EFL teaching. Moreover, in the first section, there is an introduction that discusses the background of the topic in which the writer fits in. Then, the problem and purposes in arranging this research. The second one is finding and discussion, there are some discovers result research and some relation of the previous review with the result itself. It contains the teachers' capability in 4.0 technology also students' responses with the modern learning tools. Therefore, the reader could measure that this paper is the result of study literature from many resources combines with an open-ended questionnaire which makes the matter accurate.

\section{Information and Communication Technology (ICT) in English Foreign Language (EFL)}

In the globalization era, technology important to be blended with the educational system. Contrary to that statement, Rahimi \& Yadollahi (2011) argue about ICT is rarely utilized among English teaching for foreign language. If many people neglecting this situation the possibility of educational system degradation will conduct easily. Then, as stated in Clement \& Rama (2020) teachers suggested considering global ICT while enhancing students' skills from many platforms of technology. There is no limitation of technology particularly in an educational institution. The combination between ICT and teaching methods could develop well-structured EFL teaching perhaps in language skills or language structure.

Many studies decided that modern learning strategy is related to technology rates. ICT method utilizes to create innovative teaching facilities. The study of Kizil (2011) based on the descriptive-statistic method emphasizes about ICT could increase the value of a country and enhance the educational curriculum. In the line 
with this, the study literature from Sabiri (2020) states each teacher suggests to well-adapted with the ICT in 4.0 era also have proper insight with the confident skills of teachers in ICT improvement itself. In fact, teachers' skill in the implementation of ICT in the educational institution was very low. There is no enough idea found with e-learning models or any other ICT tools. Some solutions should be conducted to face the technology development rates particularly the integration of ICT in learning models. The government pursued to make a major teaching evaluation approach with each teacher to find truly qualified teachers. However, in this online learning, designing creative learning strategy become teachers' obligation.

The current study found about teachers' capability to operates ComputerAssisted Language Learning (CALL) still in the low range. Furthermore, CALL actually important to explore strategies in teaching grammar which really in every stage of education (Bubaraye \& Effiong, 2017). Not only grammar, all over English skills need some creative execution throughout the ICT. Moreover, in this 4.0 era the technology increase quickly. By this reality, each teachers of education institution particularly English teacher pursued to have capability in mastering ICT. The expansion of integration in ICT and ELT for foreign language will bring understanding and convenience of independent learning for students itself. The inability of each English teacher in integrating ICT with the learning model must be minimalized as soon as possible.

Sub-sub Section (Time New Roman, 12pt, Italic)

If there is sub-sub section, the title should be written in italic and capitalized for each word 


\section{English Language Teaching (ELT) in English Foreign Language (EFL)}

English is a language skill that needs two sides of communication between the teachers and students. According to that, the strategy of ELT is how the teacher communicates English with each student. Then, in Indonesia English just utilize for academic purposes (Norahmi, 2014). Although Indonesian citizen is not conducting the English daily communication, the fact about English as a global language could not be denied. Related to the term of global it is mean if there is an English Language Teaching (ELT), English teachers required to implement the major reform of modern teaching method. Furthermore, the well-implemented modern teaching strategy supports the qualified output of the English learning process itself.

Nowadays, there is the limitation of teaching English as a foreign language particularly in Indonesia, which just start to be implemented in the seventh grade of middle school. Moreover, elementary schools already have no curriculum about English. In fact, this curriculum imitation does not become the best solution because autonomous learning is supposed to conduct in the early stage. Then, the survey used by Safari \& Sahragard (2015) found the new method in ELT namely "interactive self-reliance communicative approach." This kind of strategy is related to the Islamic approach which integrates with modern English teaching strategies. In contrast, communicative strategy is used as a teaching approach in the study of Jayanti \& Norahmi (2014). The reason for conducting communicative strategy is based on the background of language to communicate with each other. Moreover, that kind of approach demands us to make a relation with people around the world.

Many studies found various strategies in ELT. Teachers could not arbitrarily adopt strategies that will be utilized in class. Despite the diversity of each learning 
method which used in English classes, teachers are required to considering the class atmosphere, students' awareness also the lesson plan which has to be created. However, the appropriate strategies are supported by teachers' qualifications. The integration of ELF in EFL needs highly consideration of each teacher.

\section{B. RESEARCH METHOD}

\section{Research Design}

This research used the descriptive-qualitative method to explore how teachers' capability to integrate ICT in ELT for foreign language. The integration of ICT in ELT supported teachers to conduct the autonomous learning which needed for higher education students. Therefore, an open-ended questionnaire was used as an instrument for collecting the data from each respondent. In addition, direct observation was also conducted to add theoretical evidence so that the findings are stronger.

\section{Subject}

Six respondents pursued to answers five questions with serious detail in order to be analyzed by the researcher. Those respondents include young teachers. Young teachers often have fresh ideas and highly sensitive to technology development rates. This is the reason why young teachers requested to become respondents. Therefore, not only young teachers, there is direct observation with a senior English teacher from high school as the comparison about the productivity of English teachers while integrating the technology in classes.

\section{Data Collection}

The five following question categorize as; the importance of ICT for ELT in foreign language, the utilization of social media as the learning tools, the 
implementation of ICT which integrate with ELT in the class, the students' responses with teachers' ICT strategy and the application of student-centered or autonomous learning application in the teaching classes related to the ICT. All the questionnaire provides in English in order to make easy while analyzing process.

\section{FINDINGS AND DISCUSSION}

\section{The Importance of ICT for ELT in EFL}

The importance of ICT actually cannot be denied. Juliana \& Muslem (2017) argue about each teacher realized how powerful ICT if integrated into ELT classes. In the line with that, all the respondent of this research also gives their highly agreement about the importance of ICT in ELT. However, students who learn English think that they just learn English just for a score. There is the lowest awareness about the important implementation of English in this 4.0 era. Thus, teachers or students could make collaborate to develop effective English Learning Teaching (ELT), particularly in EFL classes. In fact, society's expectation of the English teacher is in a higher range. Looking back into the reality that English is a global language so that English teachers are required to follow and mastering well-structured communication and technology development rates.

Based on the questionnaire result, several data were found about the importance of ICT for ELT in EFL.

Q: "How important ICT for ELT in a foreign language?"

T1: "As important for various ways to teach students who not all interested in learning English. Using ICT for EFL is a fun way of learning remembering how great technology recently." 
T2: "ICT using for EFL teaching is definitely helping teacher for giving the best explanation learning in class. It has benefit to managing the class easier than manual."

T3: "it helps the teacher to interact with students. it helps in improve teaching skill, helps innovative teaching especially teaching language." T4: "Important as media to improve students' foreign language."

T5: "Very important."

T6: "It's important."

$\mathrm{Q}=$ Question

$\mathrm{T}=$ Teacher

ICT is actually useful in ELT for foreign language. All the respondents emphasize ICT is important, no one states their disagreement. Particularly in this online learning era, each teacher pursued to utilize ICT through the learning process in order to create innovative methods. By remembering how great technology for students who not interest in English, it could be one of the solutions to attracting students' attention. In addition, by applying ICT in ELT, teachers definitely get convenience while explaining the material or collecting the assignment. Thus, there is no reason to become a passive teacher without any technologies implementation in EFL classes.

\section{The Utilization of Social Media as The Learning Platform}

Young teachers and senior teachers have differences in utilize ICT as learning tools. Young teachers have a higher knowledge to applicate social media rather than senior teachers. Many teachers considering daily social media which easy to operates as the most utilization of learning tools in 4.0 era. Al-Munawwarah (2014) emphasizes through the utilization of ICT in ELT, teachers capable to think creatively and felt helped with tools which provide in modern technology. In 
contrast, the reality in Indonesia tells us that ICT is rarely to be applied. On the other hand, research findings from Lubis (2018) on teachers' competence in exploring ICT could be conducted through increase self-awareness of the teachers. Qualified teachers actually have a sensitivity to follows the modern technology approach in ELT. Social media definitely become the easiest tool because it was nearest to us. Therefore, young and senior teachers should have to balance knowledge about modern technology.

The survey found the majority of teachers only utilize one or two social media as ICT tools through the learning process. In the line with that, each teacher decides to choose social media which easy to operates daily. However, teachers just applicate minimum tools, but their awareness about the importance throughout the implementation of ICT in this 4.0 era deserves to be appreciated. Furthermore, the result showed the utilization of ICT in ELT classes.

Q: "How often you utilize social media as your learning media? Mention the most platform which you often utilize, and what the reason?"

T1: "Causing the situation and condition, we must be often using social media for learning. First, our classes were using WhatsApp for learning during class. Because it'll be much easier for communicating each other. Besides, teachers and students are almost able using this app. Second is Google Form. It's managing the class for attendance checking or for the homework."

T2: "WhatsApp and YouTube Because according to the students of SMA Muhammadiyah 1 Sokaraja, they are lack of Internet and even there are some students have problem with the phone. So using the social media which almost everyone has is the best choice that time. 
T3: "Every meeting. WhatsApp, Google meet, YouTube, and Google Form. Because all those platforms are very needed on teaching and learning especially in this pandemic situation."

T4: "I often use social media as learning media. usually I use Kahoot. the reason why I use this platform because Kahoot is funny media to children."

T5: "No often, WhatsApp because limitation of facilitate."

T6: "Most often, WhatsApp, for daily activity."

$\mathrm{Q}=$ Questions

$\mathrm{T}=$ Teacher

Almost all teachers already known about ICT tools. But, just several teachers have the capability to contribute appropriate ICT tools with classes. one until two teachers from all respondents are qualified while choosing the appropriate social media to integrate with fun learning classes. The fun platform which could be utilized as a unique strategy is Kahoot. However, this kind of platform is designed similarly to the game so most of the students will easy to learn English as a foreign language. On the other hand, the most social media utilized as a learning tool is WhatsApp. 


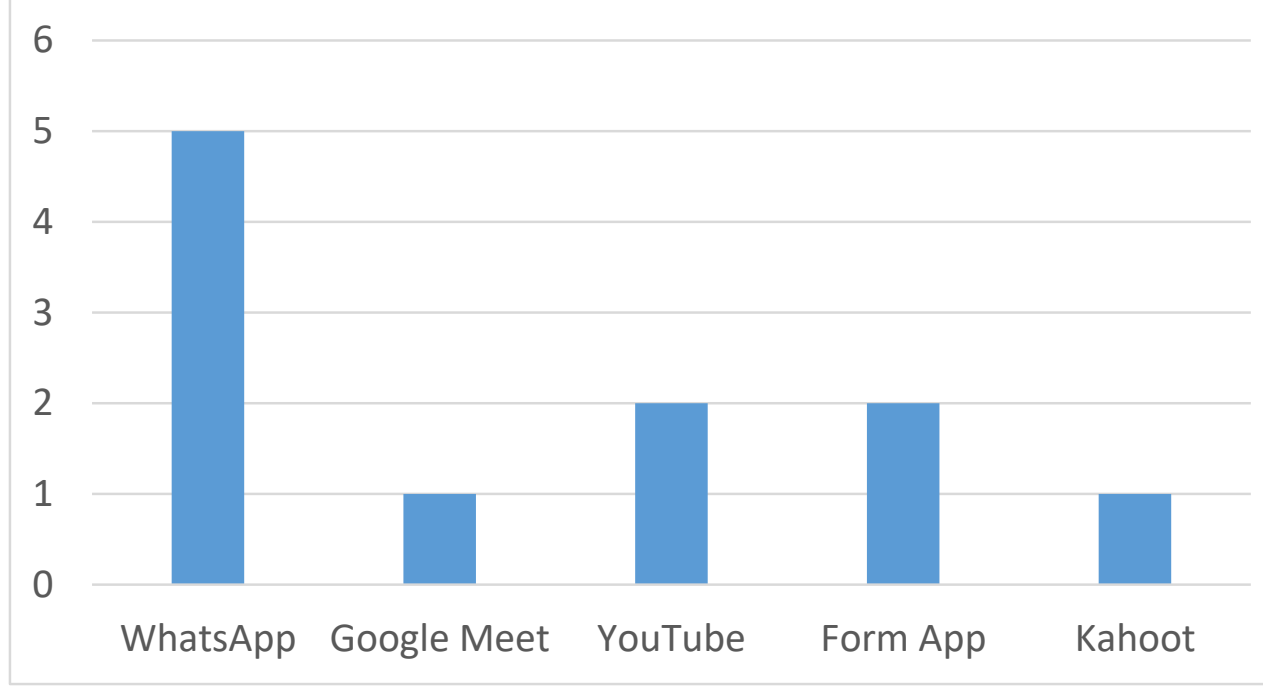

Figure 1. The Range of Social Media Utilization as ICT Tool in ELT

The figure shown about the most social media utilized by each teacher is WhatsApp. The reason why WhatsApp got the first position because WhatsApp is an application which easy to operates and most of the people have installed on their own phone. The second position is YouTube and Form App (Google Form). YouTube is the most famous application with many sources which fully support to students in learning English language skills particularly speaking skill. Meanwhile, the minority utilization ranges of social media as a learning strategy are Google Meet and Kahoot. Many teachers think that Google Meet spends a lot of quotas. They do not thing about positive value while utilizing Google Meet as learning media such could conduct a direct conference between teachers and students. Furthermore, not many teachers know to operate Kahoot because this platform not too much famous particularly in Indonesia. 


\section{The Implementation of ICT which Integrate with ELT in Classes}

The open-ended questionnaire got the data such:

Q: "How do you implement ICT which integrates with ELT in your classes?"

T1: "Actually I have been teaching English learning. In class, we used to solve problems from the Contextual questions which are needs implementation for explaining the problems. The implementation is using PPT as learning media for explaining clearly. The PPT can be explaining every step for solving problems."

T2: "I used WhatsApp for group discussing, video calls, and giving material. I used YouTube for sharing and giving the lessons. I used Google meet for giving the lesson. I used Google form for collecting the tasks."

T3: "Firstly I explain about the material, then I make some questions in Kahoot. I tell my students to open the application while I show it on the screen. then I tell them to answer all of questions."

T4: "Using voice note in explaining so the students not getting bored just using text. Choose YouTube video that provide imitation of the text, so the students can try to imitate."

T5: "Using WhatsApp for daring classes."

T6: "No."

$\mathrm{Q}=$ Questions

$\mathrm{T}=$ Teacher 
The data showed four of six respondents have the capability in well-structured class designing. This is proved with their ICT tools utilization and how they combining those tools with class conditions. Four teachers have known the distinct purpose of the importance of ICT in 4.0 era. Moreover, they explained the detailed process while integrating ICT tools with unique ELT strategies. Unfortunately, two of six teachers not giving their higher consideration within ICT in ELT. Furthermore, there is one young teacher who does not know ICT integration. This is the irony which worse than the capability of senior teachers who only utilize one or two tools in ELT. However, there is no limitation in technology integration with teaching strategies. In fact, EFL teachers should have various innovations while conduct the learning process to develop a convenient and interactive atmosphere.

\section{Students Responses with ICT Strategies}

English teachers particularly in Indonesia which pursued to teach EFL with the current technology approach. However, ICT supports autonomous learning or student-centered promotion to each student (Lubis, 2018). Thus, students' responses to the integration of ICT depend on how the implementation of ICT by the teachers. There are various ICT tools such WhatsApp, Form App, YouTube, Google Meet and Kahoot which utilize in ELT. Teachers pursued to conduct a well-structured combination of ICT tools with ELT in EFL to create habitual autonomous learning which is needed for higher education students from the early stage.

Based on the result of the research, there are various responses of students while faced the ICT as a learning tool. Before discussing them one by one, there is the data presentation from the questionnaire that we asked informants: 
Q: "How students' responses with your ICT strategy?"

T1: "From the internal cause itself is the students having low interest in learning especially English. Many of them just keep silent and even talk to the others. The respond when I using the ICT is also not good. Just some of them who respond to it."

T2: "Some of them were enjoying the class. But there's many students were ignoring my class. Because the internet learning can't control them as well.

T3: "Students' responses are good but some of them have no discipline to do online class."

T4: "they feel interest with the learning by using social media."

T5: "No, because my student still in elementary."

T6; "Excited."

$\mathrm{Q}=$ Questions

$\mathrm{T}=$ Teacher

The summaries of those all data is, several students just keep passive responses even if the ICT tools already conduct in ELT. The factors which affect that reality conducted from there is no learning control during online based. In the line with that statement, EFL is not Indonesian students' behavior. They do not yet realize how important global language in this 4.0 era. According to that reason, many students feel they do not need English learning for distinct purposes. Although many students are ignoring teachers while ELT class, there are some students who still give a nice contribution in class. Balance range conducted between active and passive students in the same percentage. However, an English teacher should develop interactive learning with attracting 
student to be active because English is a language which needs highly communication with each other.

\section{The Student-centered Application in the Teaching Classes Related to the ICT}

Student-centered or autonomous learning particularly important in this global era. To know how the development of student-centered which integrate with ICT, there are several data found from the questionnaire result:

Q: "How the student-centered application in your teaching classes related to the ICT?"

T1: "Related to the ICT, student-centered application during the online learning is just practicing by using the social media to conduct cross-correcting strategy by groups in class."

T2: "Student-centered is not going well on my class, the students only receive the material and the end of class, asking is there any task or not. They do not have any questions or etc."

T3: "I use Kahoot as a media to teach since it is a funny media to boost the interest of children."

T4: "It's useful and make my job to be easier"

T5: "Using group WhatsApp for discussion."

T6: "Make discussion."

$\mathrm{Q}=$ Questions

$\mathrm{T}=$ Teacher

In fact, ICT is actually supported by autonomous learning or student-centered. The result of the ulitization of autonomous learning is depending on how the teacher manages strategy in class. However, all students need to have the skill to become autonomous learners moreover in higher education. All the 
respondent was not given specific information from student-centered strategy. They just inform about student-centered which not going well in the class. As a teacher, we should realize to make habitual about autonomous learning is particularly important to be the mastering of each student. Then, the research found that a fun learning strategy could give a booster to the students' activeness in English classes.

\section{CONCLUSION AND SUGGESTION}

\section{Conclusion}

This study concerns examining the utilization of ICT while conducting autonomous learning and ensuring teachers' abilities implementation of social media as ICT tools to support English Foreign Language (EFL) teaching platforms. There are several points have found such, teachers have high consideration of innovation of ICT for ELT in EFL, various social media utilize as learning platforms such, YouTube, Google Meet, Form App, WhatsApp, and Kahoot, there are not enough innovations found in teachers' capability while implement of ICT in ELT, most of the student just give passive responses however the ICT have been conducted and the appropriate ICT tools could enhance the possibility of student-centered strategy.

\section{Suggestion}

Talking about the modern technology development rates is could not be separated from educational development. Those all related to each other. Therefore, as a teacher which teaches global language, we should give a high consideration of how to become innovative teachers to develop interactive English classes. Through the 4.0 era, many ICT tools easy to be utilized in the teaching process. There is no limitation of technology utilization. Moreover, the appropriate ICT tools are actually needed to increase student-centered strategy. An effective 
learning process will be gained if students and teachers could contribute to the implementation of ICT.

\section{E. REFERENCES}

Bilyalova, A. (2017). ICT in Teaching a Foreign Language in High School. Procedia - Social and Behavioral Sciences, 237, 175-178. Doi: 10.1016/j.sbspro.2017.02.060

Jayanti, N. S., \& Kumar, R. V. (2016). Use of ICT in English Language Teaching and Learning. Journal of English Language and Literatur (JOELL), 3(2), 34-38.

Azmi, N. (2017). The Benefits of Using ICT in the EFL Classroom: From Perceived Utility to Potential Challenges. Journal of Educational and Social Research, 7(1), 111-118. Doi:10.5901/jesr.2017.v7n1p111

Kizil, A. S. (2011). EFL Teachers Attitudes Towards Information and Communication Technologies (ICT). 5th International Computer \& Instructional Technologies Symposium, 22-24.

Tri, D. H., \& Nguyen, N. H. T. (2017). An Exploratory Study of ICT Use in English Language Learning Among EFL University Students. Teaching English with Technology Journal. 14(4), 32-46.

Sabiri, K. A. (2019). ICT in EFL Teaching and Learning: A Systematic Literatur Review. Contemporary Educational Technology, 11(2), 177-195. https://doi.org/10.30935/cet.665350

Clement, A. R. S., \& Ramya, D. (2020). Integration of Information and Communication Technology (ICT) Tools in English Language Teaching (ELT) from Teacher's Prespective. International Journal of Applied Engineering Research, 15(2), 108-110.

Bubaraye, I., \& Effiong, M. (2017). Teachers Use of Information and Communication Technology (ICT) in Teaching English Language in Senior Secondary Schools in Akwa Ibom State. Equatorial Journal of Education and Curriculum Studies, 2(2), 28-33.

Ammani, S., \& Apparanjani, U. (2016). The Role of ICT in English Language Teaching and Learning. International Journal of Science and Engineering Reasearch, 7(7), 1-7. 
Rahimi, N., \& Yadollahi, S. (2011). ICT Use in EFL Classes: A Focus on EFL Teachers' Characteristics. World Journal of English Language, 1(2), 17-29. http://dx.doi.org/10.5430/wjel.v1n2p17

Al-Munawwarah, S. F. (2014). Teachers' Perception on the Use of ICT in Indonesian EFL Learning Context. Journal of English Education, 3(1), 70-80.

Lubis, A. H. (2018). ICT Integration in 21st Century Indonesian English Language Teaching: Myths and Realities. Cakrawala Pendididkan, 1, 11-21.

Juliana, R., \& Muslem, A. (2017). The Use of Information and Communication Technology (ICT) Amongst EFL Teachers: Perceptions and Challenges. English Education Journal, 8(4), 469-487.

Safari, P., \& Sahragard, R. (2015). Iranian EFL Teachers' Challenges with the New ELT Program after the Reform: Form Dream to Reality. Khazar Journal of Humanities and Social Sciences, 18(4), 65-88.

Jayanti, F. G., \& Norahmi, M. (2014). EFL: Revisiting ELT Practices in Indonesia. Journal of English as a Foreign Language, 4(1), 5-14.

Sabiri, K. A. (2020). ICT in EFL Teaching and Learning: A Systematic Literature Review. Contemporary Educational Technology, 11(2), 177-195. DOI: https://doi.org/10.30935/cet.665350 